\title{
MANAJEMEN TRANSPORTASI DI DKI JAKARTA (Suatu Tinjauan Sosiologis dan Hukum )
}

\author{
Mutiara Hikmah ${ }^{1}$ \\ Herry Cahyoko ${ }^{2}$
}

\begin{abstract}
Jakarta as the capital of the country, ideally is a beautiful city, clean, orderly, comfortable and organized. But in reality, Jakarta as a metropolitan city that has typical big city, ie, traffic vehicles, large population and construction of buildings and malls, as well as many more number of activities undertaken that cause congestion. Traffic congestion in Jakarta, reflects helplessness Government of DKI Jakarta to anticipation of population growth and development of the city as well as the rapid growth of vehicle so in terms of providing transportation services of any kind can not be done. In fact, transportation is one of the benchmarks of economic resilience of a region or area. Program busway intended to be a solution to the problem of mass transportation in Jakarta, but the lane busway itself is still questionable residents, whether to tackle congestion or even add to traffic congestion in Jakarta.
\end{abstract}

Keywords: sociology, transport, local government and local regulations.

\begin{abstract}
Abstrak
Jakarta sebagai ibukota negara, idealnya merupakan kota yang indah, bersih, tertib, nyaman dan teratur. Tetapi kenyataannya, Jakarta sebagai kota metropolitan yang mempunyai ciri khas kota besar, yaitu: keramaian lalu lintas kendaraan, banyaknya penduduk dan pembangunan gedung dan mall, serta banyak lagi sejumlah aktivitas yang dilakukan yang menyebabkan timbulnya kemacetan. Kemacetan lalu lintas di Jakarta mencerminkan ketidakberdayaan Pemda DKI Jakarta dalam mengantisipasi perkembangan penduduk dan pembangunan kota Jakarta serta pertumbuhan kendaraan yang semakin pesat sehingga dalam hal memberikan pelayanan transportasi apapun tidak bisa secara baik terlaksana. Padahal transportasi adalah salah satu tolok ukur dari ketahanan ekonomi suatu wilayah atau daerah. Program busway ditujukan untuk menjadi solusi atas persoalan transportasi massa di Jakarta, namun jalur busway itu sendiri pun masih dipertanyakan warga, apakah untuk mengatasi kemacetan atau justru menambah kemacetan di wilayah DKI Jakarta.
\end{abstract}

1 Staf Pengajar FakultasHukum UI untuk kelompok Mata Kuliah Hukum Perdata Internasional, Hukum dan HAM dan Mata Kuliah Economic and Business Law di FEUI. Alamat kontak: mtiara90@yahoo.com dan Sosial.

${ }^{2}$ Ketua Serikat Pekerja Di PT Garuda Indonesia dan pemerhati masalah-masalah Ekonomi 
Kata Kunci: sosiologis, transportasi, pemerintah daerah dan peraturan daerah.

\section{Pendahuluan}

DKI Jakarta merupakan propinsi terpadat penduduknya jika dibandingkan dengan luas wilayahnya ${ }^{3}$ di negara Republik Indonesia. Berdasarkan hasil Survei Sosial Ekonomi Nasional tahun 2003-2004, jumlah penduduk miskin di DKI Jakarta sebesar 294.100 (tahun 2003) dan 277.100 (tahun 2004), dengan angka persentase sebesar 3,42\% tahun 2003 dan 3,18\% tahun 2004. Angka persentase tersebut merupakan angka terendah jika dibandingkan dari seluruh provinsi yang ada di seluruh Indonesia. ${ }^{4}$ Disamping itu, tingkat likuiditas perekonomian (uang beredar dalam arti luas) terdapat di Propinsi DKI Jakarta. ${ }^{5}$ Tidaklah heran jika DKI Jakarta sebagai Ibukota Negara RI merupakan pusat segala aktivitas kehidupan di negeri ini.

Sebagai ibukota negara, idealnya Jakarta merupakan kota yang indah, bersih, tertib, nyaman serta teratur. Namun kenyataannya, Jakarta sebagai kota metropolitan justru mempunyai ciri khas kota besar, yaitu: keramaian lalu lintas kendaraan, banyaknya penduduk dan pembangunan gedung dan mall, serta banyak lagi sejumlah pekerjaan dan kegiatan yang dilakukan dengan menggunakan jalan yang menyebabkan timbulnya kemacetan dan kesemrawutan. lalu lintas. Kemacetan dan kesemrawutan lalu lintas jalan raya di Jakarta bukan saja pada musim hujan yang menimbulkan genangan air/banjir di beberapa ruas jalan raya, tapi pada kondisi normal pun kemacetan dan kesemrawutan tidak dapat terelakkan karena kapasitas jalan memang sudah tidak sebanding dengan banyaknya jumlah kendaraan yang menggunakan jalan. Kemacetan lalulintas ini semakin diperparah dengan banyaknya angkutan umum yang bertebaran dimanamana dan sikap (baca: kebiasaan) pengemudi angkutan umum yang kurang disiplin, berhenti semaunya untuk mencari penumpang, parkir semaunya dan kadang sering ugal-ugalan dalam mengemudikan kendaraannya. ${ }^{6}$ Seringkali terlihat pengemudi angkutan umum menarikan dan menurunkan penumpang disembarang tempat, berhenti untuk mencari/menunggu penumpang di mana saja sesukanya sehingga membuat keadaan jalan menjadi stuck, macet, tidak lancar dan dan lalu lintas menjadi macet.

\footnotetext{
${ }^{3}$ Berdasarkan angka proyeksi penduduk Indonesia untuk wilayah DKI Jakarta, tahun 2005 kepadatan penduduk DKI Jakarta adalah: 13.102/km persegi. (Sumber: Badan Pusat Statistik, Statistik Indonesia: Statistical Yearbook of Indonesia 2005/2006, Jakarta: BPS, 2006), hal..63.

${ }^{4}$ Ibid., hal. 569.

${ }^{5}$ Ibid., hal. 409. Hal ini dapat dilihat dari data Realisasi Penerimaan dan Pengeluaran Pemerintah Daerah Provinsi DKI Jakarta dari 2002 sampai dengan tahun 2005, selalu mengalami peningkatan.

${ }^{6}$ Kondisi angkutan umum pun sangat memprihatinkan dari tahun ke tahun dan jumlahnya pun semakin berkurang.
} 
Selain persoalan jumlah kendaraan pribadi, angkutan umum dan sikap pengemudinya, salah satu faktor penyebab juga kemacetan lalu lintas di Jakarta adalah ketimpangan di sektor transportasi kota, berupa pertumbuhan jalan yang tidak seimbang dengan pertumbuhan kendaraan bermotor. ${ }^{7}$ Sehingga Kota Jakarta akhirnya identik dengan kemacetan dan Kesemrawutan. Jika kesan itu tidak bisa dihapus, maka kemacetan mencerminkan ketidakberdayaan Pemerintah Daerah DKI Jakarta (untuk selanjutnya disingkat dengan Pemda) dalam mengantisipasi perkembangan penduduk dan pembangunan kota Jakarta sebagai Ibu kota Negara serta pertumbuhan kendaraan yang semakin pesat juga dalam hal memberikan pelayanan transportasi massa secara baik Padahal transportasi adalah salah satu tolok ukur dari ketahanan ekonomi suatu wilayah atau daerah. Suatu sistem transportasi akan dinilai baik apabila perpindahan barang atau orang dari satu empat ke tempat lain dapat dicapai dengan selamat dan tepat waktu. ${ }^{8}$

Berdasarkan data-data terakhir yang dihimpun oleh Dinas Perhubungan Pemerintah Provinsi DKI Jakarta, keadaan di wilayah DKI adalah sebagai berikut:

1) Perkembangan jumlah kendaraan bermotor terus meningkat; ${ }^{9}$

2) Jumlah kendaraan bermotor yang bergerak setiap harinya mencapai 4,95 juta; ${ }^{10}$

3) Rasio jumlah kendaraan pribadi dibandingkan kendaraan umum adalah $98 \%$ dibanding $2 \%{ }^{11}$

4) Kemampuan menambah ruas jalan semakin sulit dibandingkan penambahan kendaraan; ${ }^{12}$

5) $85 \%$ ruas jalan yang ada digunakan oleh kendaraan pribadi yang sebenarnya hanya melayani $9,7 \%$ perjalanan (mobil).

Dengan mengacu pada refrensi data-data di atas, terlihat bahwa kondisi lalu lintas di Jakarta didominasi oleh banyaknya penggunaan kendaraan pribadi dibandingkan kendaraan umum. Selain itu perencanaan pembangunan tata ruang kota Jakarta, pengaturan/pembatasan kendaraan pribadi dan umum juga manajemen transportasi kota Jakarta yang semuanya carut marut belum diatur secara serius dalam PERDA sehingga menjadikan masalah besar persoalan

7 Muhammad Izul, Busway Culture: Budaya Baru Trasnportasi Jakarta, $<$ http://ezzelhague.multiply.com/journal/item/5>, diakses tanggal 18 Februari 2008, hal.1.

8 Kristsadipun, Kemacetan, Cermin Kelemahan Manajemen Transportasi, $<$ http://www.sinarharapan.co.id/berita/0211/02/eko11.html>, diakses pada tanggal 18 Februari 2008, hal. 2.

${ }^{9}$ Saat ini berjumlah sekitar 5,4 juta, rata-rata meningkat $7 \%$ per tahun.

${ }^{10}$ Kendaraan roda dua $53 \%$, mobil pribadi $30 \%$, bus $7 \%$, dan truk $10 \%$.

${ }^{11}$ Rasio penggunaan kendaraan pribadi dibandingkan kendaraan umum adalah $49,7 \%$ dibanding $50,3 \%$ dari total 17 juta perjalanan. per tahun.

${ }^{12}$ Panjang jalan hanya bertambah kurang dari $1 \%$, penambahan kendaraan rata-rata $11 \%$ 
transportasi massa di Jakarta yang disertai dengan rendahnya kualitas pelayanan publik di sektor transportasi, baik yang disediakan oleh PEMERINTAH/PEMDA ataupun swasta termasuk juga system pengawasan dan koordinasi dari petugas/ aparat di jalan raya.

Keadaan ini tentu amat mengkhawatirkan bagi Masyarakat Ibukota, dimana kualitas udara Jakarta semakin buruk karena banyaknya Polusi yang mengandung asap pembakaran knalpot kendaraan, banyaknya jumlah kendaraan yang beroperasi di jalan juga menjadi tambah memperburuk kualitas udara Jakarta yang sudah demikian parah. Apalagi apabila kebanyakan dari kendaraan yang beroperasi tersebut tidak berada dalam kondisi yang baik atau laik jalan. ${ }^{13}$

Pertumbuhan kendaraan bermotor di Jakara memang sudah tidak sebanding lagi dengan laju pertumbuhan jalan yang dibangun Pemerintah Daerah setempat. Sementara, total luas jalan di DKI Jakarta, baik jalan tol, jalan arteri, jalan kolektor maupun jalan lokal adalah 41,5 kilometer persegi. Jadi disini terlihat bahwa pertambahan luas jalan tidak dapat mengejar laju pertumbuhan kendaraan yang demikian pesat. Akhirnya terjadilah kemacetan lalu lintas disana sini.

Sebagai pembanding kepadatan lalu lintas dan luasnya Jakarta maka kita perlu juga melihat dan membandingkan ibu kota negara kita dengan kota dibeberapa negara seperti: Jeddah, Tokyo, Singapura, atau negara tetangga terdekat Malaysia/yaitu Kuala lumpur.

1) Jeddah, jumlah penduduk kota 3.400 .000 dengan kepadatan $2,921 / \mathrm{km}$ persegi, ${ }^{14}$

2) Tokyo luas wilayah $2.187,08 \mathrm{~km}$ persegi, jumlah penduduk kota 12.369.000, kepadatan $5.655 / \mathrm{km}$ persegi ${ }^{15}$

3) Singapura, jumlah penduduk kota 4.553 .000 , kepadatan $6.669,1 / \mathrm{km}$ persegi ${ }^{16}$

4) Kuala lumpur jumlah penduduk kota 1.556 .200 , kepadatan $243 / \mathrm{km}$ persegi.

13 Teguh Kurniawan, Manajemen Transportasi dan Kualitas Udara Jakarta, $<$ http://www.sinarharapan.co.id/berita/0306/24/opi02.html>, diakses pada tanggal 18 Februari 2008, hal.1.

Pada artikel tersebut, Teguh Kurniawan memaparkan hasil survey yang pernah dilakukan oleh Badan Lingkungan Hidup Dunia/UNEP pada tahun 2003, yang telah menempatkan Jakarta sebagai kota terpolusi ketiga di dunia setelah Mexico City dan Bangkok. Diungkapkan oleh UNEP bahwa sumber utama polusi di Jakarta adalah asap kendaraan bermotor dengan kontribusi sebesar $67 \%$ dari total penyebab kotornya udara Jakarta. Pada tahun yang sama survey dilakukan oleh CIRUS (Center for Indonesian Regional and Urban Studies) dan diketahui bahwa jumlah perjalanan per hari penduduk DKI Jakarta setiap tahunnya sebanyak 15,7 juta orang, dimana dari jumlah tersebut hanya 2,9 juta orang saja yang menggunakan sarana bis kota.

${ }^{14}$ Sumber: <http://en. wikipedia.org/wiki/Jeddah>, diakses pada tanggal 14 Maret 2008.

15 Sumber: <http://www.Japaneselifesyle.com.au/tokyo_population.htm>. diakses pada tanggal 14 Maret 2008.

${ }^{16}$ Sumber: <http://world.bymap.org/population.html>, diakses pada tanggal 14 Maret 2008. 
Jika kita bandingkan dengan ibukota negara-negara lain diatas, memang Jakarta adalah ibukota dengan tingkat kepadatan duduk tertinggi. Akhirnya tidaklah heran salah satu problema sosial yang dihadapi oleh pemerintah daerahnya adalah kemacetan lalu lintas.

Persoalan kemacetan lalu lintas di DKI Jakarta berpangkal pada problem strktural berupa; perencanaan pengembangan pembangunan tata ruang kota Jakarta. Pengaturan kendaraan pribadi dan umum juga manajemen transportasi kota Jakarta yang semuanya carut marut tidak dibuat/diatur secara komprehensif sehingga manajemen transportasi kota Jakarta yang ada menjadi tidak effektif yang menjadikan persoalan besar transportasi massa di Jakarta dan disertai dengan rendahnya kualitas pelayanan publik di sektor transportasi, baik yang disediakan oleh Pemerintah Pusat maupun Daerah ataupun swasta. ${ }^{17}$ Keberadaan Program busway ditujukan untuk menjadi solusi atas persoalan transportasi massa di Jakarta. ${ }^{18}$ Namun jalur - jalur busway itu sendiri pun masih menjadi persoalan dan banyak dipertanyakan warga, apakah untuk mengatasi kemacetan atau justru menambah parah kemacetan yang sudah parah di kota metropolitan ini. Terlepas dari pro dan kontra tentang busway, diakui bahwa ada beberapa kelebihan yang dapat dirasakan dengan adanya fasilitas busway, antara lain: ${ }^{19}$

1) Kenyamanan; ${ }^{20}$

2) Keamanan; ${ }^{21}$

3) Ketepatan waktu; ${ }^{22}$

4) Pengembangan sektor transportasi massa. ${ }^{23}$

${ }^{17}$ Muhammad Izul, Loc. Cit., hal. 1.

18 Busway yang mulai beroperasi sejak 15 Januari 2004, sekilas justru menambah kemacetan lalu lintas karena otomatis lebar ruas jalan semakin berkurang. Namun penciptaan kemacetan baru bagi pengguna kendaraan pribadi ini justru disengaja untuk menggeser dan mengalihkan penggunaan sarana transportasi pribadi ke transportasi umum. Lihat: Muhammad Izul, Ibid., hal. 2.

${ }^{19}$ Ibid., hal. 3.

${ }^{20} \mathrm{Hal}$ ini bisa dibuktikan dengan fakta-fakta berupa bus yang berkapasitas luas dengan kursi busa dan ber-AC, tersedianya kotak P3K, pintu hidrolik otomatis, hingga sistem headway per tiga menit yang menepis kekhawatiran akan ketidakpastian jadwal keberangkatan busway.

${ }^{21}$ Adanya penempatan satgas di JPO, halte dan di dalam bus menjadi bukti adanya upaya pemerintah melalui BPTB memenuhi kebutuhan konsumen akan rasa aman dalam menggunakan kendaraan umum.

${ }^{22}$ Karena busway satu-satunya transportasi yang bebas macet dan bebas hambatan, maka hanya diperlukan waktu sekitar 45 menit dari Blok M sampai Stasiun Kota. Hal ini merupakan efisiensi waktu yang sangat berharga bagi masyarakat Jakarta yang memiliki aktivitas kesibukan sangat tinggi.

${ }^{23}$ Nilai investasi ekonomi untuk proyek busway terhitung paling murah dibanding monorel dan subway. 
Beberapa kelebihan inilah yang menjadikan busway sebagai pilihan pertama dalam revolusi sistem transportasi massa di Jakarta, yang rencananya akan diikuti oleh kota-kota besar lain di Indonesia (seperti Yogyakarta). ${ }^{24}$

Dibalik kelebihan-kelebihannya, ada juga kelemahan-kelemahannya yang bersumber dari keluhan masyarakat terhadap busway sebagai fasilitas baru yang diperkenalkan sejak Gubernur Sutiyoso itu, antara lain:

1) Jumlah Bus tidak sebanding dengan jumlah penumpang sehingga pada setiap halte Bus dan pergantian Jalur terutama dan pada jam-jam sibuk pagi dan sore, terlihat penumpang berdesak -desakan dan menunggu Bus yang akan di naiki tsb

2) Halte busway tidak tersedia tempat duduk dan juga tidak ber-AC, jika calon penumpang cukup banyak maka situasinya menjadi tidak nyaman (sumpek dan panas ) dan waktu tunggu berkisar antara 20 sampai 30 menit pada saat jam sibuk;

3) Bus didesain untuk banyak ruang bagi penumpang berdiri di dalam bus, sehingga tempat duduk terbatas maka naik harus berebutan (walaupun antri awalnya )

4) Jika kebetulan mendapat posisi berdiri di dalam bus, sangat tidak nyaman ketika bus mengerem dan supir menancap gas. Penumpang bisa oleng dan limbung; ${ }^{25}$

5) Halte busway didesain dengan jalan kaki dari pinggir jalan raya ke lokasi yang terletak di atas dan di tengah jalan raya, dimana jaraknya cukup jauh. Ada juga halte transisi antar koridor tetapi jaraknya sangat panjang sekali.

6) Perlu di pikirkan pada wilayah di pinggir kota tempat parkir kendaraan untuk warga masyarakat pemilik Mobil pribadi dan motor yang menjadi pengguna BUSWAY yang dikelola PEMDA.

Namun terlepas dari segala kekurangan-kekurangannya, keberadaan busway telah menciptakan budaya baru bertransportasi di Jakarta sekaligus menjadi simbol pelayanan sektor transportasi yang memanusiawikan warga. Selain itu, keberadaan busway juga menjadi bukti bahwa pelayanan publik yang memuaskan masyarakat pun bisa terwujud asal ada kemauan (political will) dari pemerintah daerah setempat.

\section{Pembahasan}

1. Kendala-kendala yang Dihadapi oleh Pemerintah DKI Jakarta dalam Mengembangkan Pembangunan Tata Ruang Kota dan Hubungannya dengan Manajemen Transportasi

\section{${ }^{24}$ Ibid.}

${ }^{25} \mathrm{Hal}$ tersebut berbeda jika dibandingkan dengan menggunakan transportasi Kereta Api Ekspress, yang posisinya sama-sama berdiri dan ber-AC tetap masih lebih nyaman karena karena gerakan kereta tidak se-oleng busway dan posisi ngerem dan ngegasnya pun lebih halus. 
Dalam hal pengembangan tata ruang kota dan hubungannya dengan manajemen transportasi di Jakarta, ada beberapa kendala yang dihadapi oleh pemerintah daerah setempat, antara lain:

1) Sinkronisasi peraturan daerah (PERDA) dan UU tentang: Jakarta sebagai Ibukota Negara, pengembangan pembangunan di Jakarta, Pengaturan kendaraan umum dan pribadi, tentang ketentuan pengguna jalan dan masalah lalu lintas di jalan baik dalam kota dan lalu lintas jalan di daerah dan antar daerah.

2) Pengwasan, penegakkan dan pelaksanaan tertib peraturan lalu lintas oleh aparat dan petugas penegak hukum.

3) Taraf kepatuhan dan ikut serta peran warga masyarakat terhadap peraturan lalu lintas dan kontribusinya untuk mencegah kepadatan kendaraan di Jakarta

Ad.1) Dalam hal sinkronisasi peraturan-peraturan daerah dan UU tentang Jakarta sebagai Ibukota Negara, pengembangan pembangunan di Jakarta, Pengaturan kendaraan umum dan pribadi, tentang ketentuan pengguna jalan dan masalah lalu lintas di jalan baik dalam kota dan lalu lintas jalan di daerah dan antar daerah. Belum adanya Undang Undang tentang pengembangan pembangunan dan tata ruang kota Jakarta dan lalu lintas jalan di Jakarta adalah: suatu keadaan yang menunjukkan adanya kaitan yang tidak selaras atau serasi antara peraturan-peraturan yang tertulis yang dikeluarkan oleh Pemerintah Pusat dan Pemerintah Daerah setempat. Disamping itu, sinkronisasi adalah menyangkut integrasi dari program-program yang ditawarkan dari program-program lain yang seharusnya dilakukan. Program three in one yang merupakan program pembatasan akses lalu lintas. Program tersebut di lapangan ternyata juga tidak didukung atau diintegrasikan dengan program terkait lainnya dalam hal ini berkaitan dengan pembatasan alokasi lahan parkir serta peningkatan kualitas pelayanan angkutan umum. Bagaimana mungkin para pengguna mobil pribadi mau mengganti penggunaan kendaraan pribadinya dengan angkutan umum, sementara pelayanan angkutan umum yang tersedia selama ini tidak nyaman dan tidak terjamin keamanan dan keselamatannya.

Ad.2) Penegakkan dan pengawasan peraturan lalu lintas oleh aparat penegak hukum, sangat berkaitan dengan sikap dan moral para penegak hukum (dalam hal ini polisi lalu lintas jalan raya dan Petugas dari Dinas lalu lintas angkutan jalan raya). Menurut kenyataan sehari-hari dan dapat diamati, bahwa penegakan dan pengawasan hukum secara mental lembaga dan oknum petugas sendiri tidak bisa memberikan contoh yang baik di jalan raya, misalnya kelengkapan rambu-rambu lalu lintas dan peralatan sarana maupun pra sarana yang kurang memadai. Ketika Pengguna jalan tidak memasang segi tiga pengaman, parkir mobil di atas trotoar, melanggar rambu-rambu lalu lintas yang ada dan, bahkan menawarkan "perdamaian" kepada 
pelanggar lalu lintas dengan tawar menawar harga untuk damai secara terang-terangan. Sarana dan pra sarana serta fasilitas di jalan raya perlu dilengkapi selain untuk petugas dan aparat penegak hukum, juga untuk kenyamanan dan keamanan pemakai jalan. Termasuk kerusakan pada jalan yang berlobang dan adanya galian dari Dinas pekerjaan Umum atau dari pekerjaan kontraktor maka harus jelas pekerjaan tsb dan berapa lama penyelesaiannya.

Pada beberapa Kota di Negara maju seperti: Tokyo. Pekerjaan untuk menambal atau melapisi aspal, membuat lobang galian dan goronggorong dll, dikerjakan pada waktu malam hari dari pk. 19.00 malam s.d pk. 05 pagi hari, dimana pekerjaan tsb tidak mengganggu pemakai jalan. Dan pada waktu pagi hari kondisi telah normal kembali sebagaimana keadaan semula tidak ada tampak pekerjaan di malam hari

Di Jakarta dan kota - kota besar lainnya di Indonesia semua pekerjaan pembangunan, pemakai jalan, perbaikan dan perawatan pada jam kerja yang sama waktunya, yaitu: pada siang hari, sehingga yang terjadi pada waktu siang adalah: kepadatan, kesibukan, kesemrawutan lalu lintas dan juga keramaian kendaraan dengan campur baur para pengguna jalan dan pekerja lainnya dan juga dengan mereka yang sedang memperbaiki jalan, galian,lobang dll. Belum lagi pekerja yang seharusnya bisa dikerjakan malam hari seperti: Pekerja Pengangkut sampah, Truck pembawa bahan bangunan dll, dengan minimnya peraraturan dan aparat dalam pengawasan maka yang timbul kemacetan lalu lintas dimana-mana.

Dari beberapa kenyataan tersebut, dapat dijadikan salah satu indikator bahwa pengawasan dan peraturan lalu lintas belum diimplemaentasikan dan tegakkan secara maksimal, karena faktor penegaknya sendiri. Jika peraturan lalu lintas belum ditegakkan dengan maksimal, maka Jakarta yang tertib dan tentram masih jauh dari harapan.

Ad.3) Secara teori, taraf kepatuhan masyarakat terhadap peraturan lalu lintas memang sangat tergantung pada taraf pengetahuan mereka terhadap hukum, sikap dan pola prilakunya terhadap hukum atau peraturan itu sendiri. Mengenai taraf kepatuhan warga masyarakat Jakarta terhadap peraturan lalu lintas, memang belum pernah ada penelitian yang dilakukan. Namun secara umum dapat diamati bahwa pengguna jalan raya pada umumnya mentaati rambu-rambu atau peraturan lalu lintas yang ada, jika nyata-nyata ada petugas yang berada di kawasan mereka berada. Jika tidak ada petugas, seringkali warga masyarakat tidak mengindahkan peraturan lalu lintas yang ada. Sebagai contoh, tidak menyebrang melalui tangga penyebrangan, melanggar rambu lalu lintas yang bertanda Letter $S$ 
atau Letter $P$, menerobos lampu lalu lintas, berbelok pada tikungan yang ada tanda dilarang berbelok atau memutar balik, dan lain-lain. Masyarakat bila dikategorisasikan berdasarkan taraf kepatuhan terhadap hukum secara relatif, maka terdapat penggolongan sebagai berikut: $^{26}$

a. Golongan warga masyarakat yang patuh;

b. Golongan warga masyarakat yang menyimpang;

c. Golongan warga masyarakat yang menyeleweng;

d. Golongan warga masyarakat penyeleweng yang sedang menjalani hukuman;

e. Golongan warga masyarakat bekas penyeleweng.

Selain kendala-kendala yang dihadapi oleh Pemerintah Daerah DKI Jakarta, sebenarnya ada kekuatan/kelebihan juga yang dimiliki oleh wilayah DKI Jakarta, antara lain pertama, jumlah penduduk yang besar, jika sumber daya manusia dapat diberdayakan dan dimanfaatkan serta dilibatkan dalam hal mengembangkan manajemen transportasi di wilayah DKI Jakarta, merupakan asset yang sangat berharga bagi pemerintah daerah setempat.

Selain jumlah penduduk, ada beberapa faktor lain yang juga menjadi kekuatan bagi wilayah DKI Jakarta, yaitu kedua, angka kemiskinan yang rendah dibandingkan angka kemiskinan dari semua wilayah lain yang ada di Indonesia. Hal ini dapat dilihat dari data Realisasi Penerimaan dan Pengeluaran Pemerintah Daerah Provinsi DKI Jakarta dari 2002 sampai dengan tahun 2005, selalu mengalami peningkatan. Faktor ketiga yaitu tingkat likuiditas perekonomian (uang beredar dalam arti luas)' yang relatif tinggi. Dari data-data tersebut berarti taraf hidup warga DKI Jakarta lebih tinggi dan pendapatannya pun relatif besar. Sebenarnya keadaan ini merupakan faktor potensial dan dominan bagi Pemerintah DKI Jakarta untuk memfasilitasi transportasi publik yang menjamin kenyamanan dan keamanan mereka. Dapat diperkirakan bahwa tidak sulit bagi warga Jakarta untuk beralih dari bertransportasi dengan kendaraan sendiri ke transportasi umum. Berikan dulu jaminan kenyamanan dan keamanan kepada warga untuk mengalihkan budaya transportasinya.

\section{Prinsip-prinsip Dasar Manajemen Transportasi dan Aplikasinya Terhadap Pengembangan Manajemen Transportasi Jakarta}

Ada dua paradigma dalam hal pengembangan manajemen transportasi, yaitu pertama prinsip car mobility dan kedua prinsip accesibility. Dengan prinsip car mobility, maka pemerintah banyak membangun sarana seperti jalan tol, jalan layang, jalan arteri. Karena tertarik membangun jalan, maka kemacetan kota besar timbul dimana-mana, karena orang lebih tertarik menggunakan mobil. Padahal di Korea jalan-jalan layang dan jalan-jalan tol

26 Soerjono Soekanto, "Suatu Tinjauan Sosiologi Hukum Terhadap Masalah-Masalah Sosial", cetakan kedua, (Bandung: PT Citra Aditya Bakti, 1989), hal. 92. 
mulai diruntuhkan, karena hal itu sama saja dengan memotivasi warga masyarakat untuk menggunakan mobil dari luar kota ke dalam kota.

Jika ukuran transportasinya dengan prinsip accesibility, maka paradigma yang dibangun adalah bagaimana menciptakan infrastruktur transportasi yang yang mudah diakses publik. Seperti misalnya kereta, monorail, atau busway. Jika prinsip accesibility sudah mulai dibangun, maka akan ada pilihan bagi masyarakat. Orang akan sedikit demi sedikit meninggalkan mobil pribadinya dan memilih transportasi umum karena jauh lebih murah. Namun yang perlu diingat, transportasi itu menjamin rasa aman dan nyaman. Hal ini tentu saja sangat berkaitan dengan kebijakan angkutan kota dan lalu lintas jalan raya yang dibuat oleh pemerintah daerah setempat.

Kebijakan angkutan kota dan lalu lintas jalan raya, selayaknya diserasikan dengan perkembangan suatu wilayah perkotaan. Demikian juga dengan kebijakan angkutan kota dan lalu lintas jalan raya di wilayah kota Jakarta.

Berdasarkan beberapa hal di atas, maka perlu direncanakan program angkutan kota dan lalu lintas jalan raya yang sesuai dengan rute yang diperlukan dan serasi dengan perkembangan wilayah kota Jakarta. Menurut Soerjono Soekanto, dalam hal perencanaan serta pengembangan lalu lintas di wilayah kota pada dasarnya dikenal adanya tiga rute, yaitu: ${ }^{27}$

a. Rute utama yang ciri-cirinya adalah sebagai berkut:

i. jalannya lebar;

ii. lalu lintas relatif ramai dan padat;

iii. menghubungkan pusat-pusat pemukiman, pusat perkantoran dan pusat perdagangan.

b. Rute cabang yang ciri-cirinya adalah sebagai berikut:

i. jalannya tidak begitu lebar;

ii. lalu lintasnya tidak terlalu ramai atau sedang-sedang saja;

iii. menghubungkan suatu wilayah denga rute utama,

c. Rute lokal yang ciri-cirinya adalah sebagai berikut:

i. jalannya kecil;

ii. lalu lintas agak sepi;

iii. menghubungkan daerah pemkimsn dengan tempat perhentian kendaraan umum di rute utama atau rute cabang.

Pada masing-masing rute tersebut dioperasikan jenis-jenis kendaraan tertentu, agar angkutan kota dan lalu lintas jalan raya berjalan secara aman dan efisien. Misalnya pada rute utama, dioperasikan bus besar dengan kapasitas 90 penumpang, bus biasa yang berkapasitas 45 penumpang. Pada rute cabang dioperasikan minibus yang berkapasitas 20 penumpang, dan pada rute lokal dioperasikan mikrolet yang mempunya kapasitas 10 penumpang.

${ }^{27}$ Soerjono Soekanto, Ibid., hal. 96. Dengan mengacu pada pembagian Soerjono Soekanto ini, maka kami akan memberi pembagian itu dengan istilah: Ring 1, Ring 2 dan Ring 3. 
Dalam kaitan mengembangkan sarana transportasi Jakarta yang sekarang dengan pertumbuhan dan perkembangan kota Jakarta yang secara tumpang tindih dan tidak konseptual ini maka perlu di lakukan upaya maksimal terhadap prinsip dasar manajemen transportasi yaitu:

I. Pemerintah harus selalu melakukan upaya dalam memberikan pelayanan masyarakat (public service) secara umum dan jangka panjang dimana dalam pengembangan tersebut sudah dilakukan kajian - yang mendalam yang melibatkan beberapa unsur ,pakar dan juga praktisi. Untuk jangka waktu tertentu, sehingga tujuan dan pengembangan pembangunan sarana transportasi bukan sekedar bisnis dari pemerintah/Pemda (oknum) akan tetapi merupakan bagian dari pelayanan yang diberikan PEMERINTAH/PEMDA. kemudian selalu dilakukan evaluasi terhadap kebijakan sarana tersebut.

Seperti: Bus way, Monorail, Taxi dll

II. Pemerintah Daerah DKI juga harus ikut memikirkan image dan keindahan Kota Jakarta sebagai Ibu kota Negara dan kota bisnis, sehingga masyarakat dapat dengan mudah mencapai Pusat Pemerintahan dan Pusat Bisnis sehingga perlu membuat terobosan yang mempermudah akses untuk semua kalangan dapat mencapai tempattempat tersebut dengan system transportasi yang terprogram.

Seperti: Pertegas lagi wilayah Area Ring 1, ring 2 dan ring 3 dan area supporting

a) Kendaraan Pribadi yang masuk wilayah area Ring 1. adalah: Kendaraan Pejabat tinggi Negara/Pemerintahan, Pejabat Departemen, pejabat Lembaga Tinggi negara, DPR/D, Pemda, kendaraan diplomat Negara Kedutaan, Negara sahabat tetangga dan Tamu Negara. Dan Tidak berlaku program 3 in $\mathbf{1 /}$

b) Kendaraan umum yang bisa masuk/lewat adalah TAXI (Class 1) serta BUSWAY. Semua jenis kendaraan dibawah roda 4 dilarang lewat/melintasi area tersebut.

c) Kendaraan pribadi yang masuk wilayah area Ring 2. adalah: Kendaraan pribadi jenis sedan dan keluarga/van dan tahun produksi maksimal tahun 1998 keatas (life time: 10 tahun), kemudian dengan pembatasan dilakukan program 3 in 1 pada jam - jam tertentu pagi dan sore dan juga dapat di perluas secara bertahap baik waktu maupun areanya menjadi area pebisnis yang aman nyaman dan bisa on time.

d) Kendaraan Umum yang bisa masuk/melintasi adalah TAXI (Class 1-3) serta BUSWAY BUS DALAM KOTA/PATAS AC dan kendaraan jenis angkot yang jumlahnya dibatasi dan sudah beroperasi maks hanya: 5 tahun (tergantung fisik dan uji kelayakan), untuk kendaraan roda 2 yang akan melewati jalan ini, masa operasionalnya maksimum adalah: 10 tahun (setiap tahun bertambah maka kendaraan pada tahun yang lama akan menjadi 
tidak berlaku) semua jenis kendaraan roda 3 dilarang lewat melintasi area tersebut..

e) Kendaraan pribadi yang masuk wilayah area Ring 3, adalah: Kendaraan pribadi jenis sedan dan keluarga/van dan tahun produksi maks th. 1998 keatas (life time: 15 Tahun), dan tergantung phisik dan kelayakan kendaraan tersebut.

f) Kendaraan Umum yang bisa masuk/melintasi adalah TAXI (Class 1-5) serta BUS DALAM KOTA/PATAS dan kendaraan jenis angkot yang jumlahnya dibatasi dan sudah beroperasi maks hanya: 7 tahun (tergantung phisik dan Uji kelayakan), untuk kendaraan roda 2 yang akan melewati jalan ini, masa operasionalnya maksimum adalah: 12 tahun (setiap tahun bertambah maka kendaraan pada tahun yang lama akan menjadi tidak berlaku) semua jenis kendaraan roda 3 beroperasi di area tersebut.

III. Pemerintah Daerah harus mengupayakan dengan harga terjangkau dan murah sarana transportasi masyarakat Jakarta dan terjangkau dengan tingkat kehidupan ekonomi masyarakat Jakarta dan sekitarnya ini.

Hal ini dengan tentunya dengan berbagai upaya yang dilakukan Pemerintah/Pemda sehingga menjadikan Jakarta sebagai Ibukota Negara yang Indah, dan Nyaman serta mempunyai Martabat tinggi di mata negara Tetangga/Dunia, serta dalam beberapa kegiatan usaha, bisnis dan event dapat tercapai dengan tepat waktu. Adapun kiat -kiat yang di buat Pemda dengan cara:

1) Memperbanyak jumlah armada BUSWAY yang ada sekarang dengan menjadikan 3x lebih banyak jumlahnya sehingga penumpang tidak berdesak-desakan, berebut, dan terlalu lama menuggu kedatangan setiap bus. Maksimal keberangkatan bus setiap 5 menit pada jam sibuk pagi $(07.00-10.00)$ dan Sore (17.00-19.00)

2) Memperbanyak Jalur/Koridor yang ada sekarang dari wilayah di Area ring 3 ke semua wilayah area Ring 2, tanpa harus masuk dalam Central terminal.

Contoh; Busway Koridor 2 Kalideres - Harmoni dan Koridor 3 Pulo Gadung - Harmoni, bisa langsung menjadi Koridor 2/3 Pulogadung - Kalideres sehingga tanpa masuk Terminal Harmoni dapat langsung ke halte sekitarnya demi efisiensi waktu dan tenaga.

1) Untuk jangka waktu kedepan mungkin perlu dipikirkan Armada BUSWAY Khusus untuk pelajar/Mahasiswa dan Pegawai Wanita dan Lansia (50 tahun keatas), terutama pada jam jam sibuk pagi dan Sore hari, sehingga dirasakan ada kenyamanannya dan ada nilai penghargaan kepada Warga Masyarakat.

2) Pada Wilayah Area Ring 3 disekitar terminal Kali deres (Wilayah Barat) Kp Rambutan (Wilayah Timur) Lebak Bulus (Wilayah Selatan) dan Tanjung Priok (Wilayah Utara). 
Pemda membuat Central Terminal BUSWAY (yang sekarang ada di Harmoni) lengkap dengan Lapangan Parkir yang cukup memadai untuk parkir kendaraan pribadi/mobil dan motor dengan kapasitas $1000-2000$ mobil dan motor juga sebagai tempat penitipan kendaraan dengan tarif murah. Dimana fasilitas parkir tsb juga ada di beberapa halte Busway di Area Ring 2. untuk kapasitas 100 - 200 kendaraan mobil dan motor. Biaya parkir bisa bulanan (abonemen) dan tarif parkir harian dengan maksimum Rp 10.000 (sepuluh ribu) per mobil dan motor Rp 5.000 (lima ribu rupiah)

Secara sosiologis, tampak adanya perkembangan jumlah kendaraan bermotor di wilayah Jakarta yang relatif pesat. Perkembangan itu ditandai dengan terjadinya peningkatan rata-rata sebesar $7 \%$ per tahun yang saat ini berjumlah sekitar 5,4 juta.

Dari segi geografis, maka Jakarta merupakan kota dimana di dalamnya terdapat suatu sistem jaringan kehidupan manusia yang ditandai dengan kepadatan penduduk yang tinggi dan diwarnai dengan strata sosial-ekonomi yang heterogen. ${ }^{28}$ Disamping itu, Jakarta merupakan wilayah yang setiap hari dikunjungi oleh warga masyarakat yang tinggal disekitarnya secara rutin. $^{29}$

Masalah-masalah pokok yang perlu diperhatikan pada proses pengembangan wilayah kota Jakarta, mencakup segi-segi: ${ }^{30}$

a) Kehidupan sosial-ekonomis; Beberapa hal yang terkait dengan kehidupan sosial ekonomis adalah: kependudukan, tenaga kerja, tingkat kemakmuran ekonomis, pemilikan kendaraan pribadi.

b) Kehidupan yang tertib dan tentram; Masyarakat dapat dikategorisasikan ke dalam beberapa golongan tertentu; Kategorisasi ini dilandaskan pada taraf kepatuhan hukum secara relatif.

c) Perkembangan kota; Beberapa masalah pokok perkembangan kota antara lain: tanah, prasarana kota, dan lingkungan.

d) Angkutan kota dan lalu lintas jalan raya; Beberapa masalah yang berkaitan dengan angkutan kota dan lalu lintas jalan raya antara lain: jaringan jalan raya, angkutan kota, sedan dan sepeda motor, ${ }^{31}$ serta parkir kendaraan bermotor. ${ }^{32}$

${ }^{28}$ R. Bintarto, "Interaksi Desa-Kota dan Permasalahannya", (Jakarta: Ghalia Indonesia, 1983), hal. 36.

${ }^{29}$ Data terakhir dari Dinas Perhubungan Pemprov DKI Jakarta, menggambarkan bahwa terdapat 600.000 kendaraan (1,2 juta orang) dari Bogor, Tangerang, Depok dan Bekasi masuk Jakarta setiap hari.

${ }^{30}$ Soerjono Soekanto, Op. Cit., hal. 91.

${ }^{31}$ Bertambahnya mobil sedan di kota Jakarta menimbulkan masalah, oleh karena rata-rata setiap mobil hanya mengangkut 2 sampai 3 penumpang, sehingga penggunaan jalan raya dengan jenis kendaraan ini kurang efisien. Bertambahnya sepeda motor secara pesat menimbulkan 
Angkutan kota dan lalu lintas jalan raya yang aman dan efisien di kota Jakarta sudah merupakan kebutuhan warga kota Jakarta dan sekitarnya. Mengenai efisiensi ini, Bonavia menyatakan bahwa "...the collective demand for transport of an organized society with a high standard of living may be exceedingly strong, since the entire mechanism for satisfying primary demands may, ... rest upon efficient transport". ${ }^{33}$

Selanjutnya Bonavia menambahkan bahwa "The effects of transport have been twofold. On the one hand, trough promoting specialization a higher standard of living has been made possible; on the other hand, trough the spread of information and ideas, the desire for improvement has been fortified". 34 "

Apabila program angkutan kota dan lalu lintas jalan raya di wilayah Jakarta diterapkan untuk menyerasikan dengan perkembangan kota Jakarta, maka hal itu merupakan suatu inovasi bagi warga kota Jakarta. Inovasi adalah: ${ }^{35}$

... an idea, practice, or object that is perceived as new by an individual or other unit of adoption. It matters little, so far as human behavior is concerned, whether or not an idea is "objectively" new as measured by the lapse of time since its first use or discovery. The perceived newness of the idea for the individual determines his or her reaction to it. If the idea seems new to individual, it is an innovation.

Proses inovasi akan menyangkut pelbagai pihak, antara lain: Change agency, Agent of Change dan clients. ${ }^{36}$ Change Agency merupakan pihak yang merumuskan program-program angkutan kota dan lalu lintas jalan raya. Agent of Change adalah pihak yang bertugas melembagakan pola angkutan kota dan lalu lintas jalan raya di masyarakat. Clients merupakan warga masyarakat yang mempergunakan angkutan kota dan pemakai jalan raya. Oleh karena itu, Agent of Change memegang peranan yang sangat penting karena agent of change merupakan pihak yang mempunyai

masalah lain, oleh karena kecepatannya yang tinggi dan kelincahannya, sehingga tidak jarang mengganggu keamanan lalu lintas.

${ }^{32}$ Kurangnya tempat parkir kendaraan bermotor (yang semakin banyak) menyebabkan terjadinya hambatan pada kelancaran lalu lintas, karena seringkali kendaraan bermotor diparkir berlapis-lapis sehingga mengurangi efektivitas lebarnya jalan raya. 1966), hal. 4.

${ }^{33}$ M.R. Bonavia, "The Economics of Transport", (Cambridge: Cambridge University Press,

${ }^{34}$ Ibid., hal. 10.

${ }^{35}$ Everett M. Rogers, "Diffusion of Innovations”, (New York: The Free Press, 1983), hal. 11.

${ }^{36}$ Ibid., hal. 312-314. 
pengaruh dan sangat menentukan dalam hubungannya dengan angkutan kota dan lalu lintas jalan raya.

Dalam proses inovasi, harus diketahui dengan tepat golongan warga masyarakat yang manakah yang paling terbuka terhadap pembaharuan. Disamping itu, golongan tadi juga menjadi panutan bagi golongan-golongan lainnya dalam masyarakat yang bersangkutan. Jika kategorisasi warga masyarakat seperti penggolongan di atas, maka golongan masyarakat yang relatif tinggi kepatuhan hukumnya dapat dijadikan golongan sasaran pertama proses inovasi. Kepada mereka pertama-tama harus ditanamkan keyakinan bahwa norma-norma lalu lintas yang berlaku adalah benar dan baik, termasuk pola angkutan kotanya.

\section{Pendekatan dari Segi Kepemimpinan, Starategi dan Pemikiran Kritis Sehubungan dengan Pengembangan Manajemen Transportasi Jakarta}

Ada beberapa pendekatan dari segi kepemimpinan, strategi dan pemikiran kritis dalam rangka mengembangkan manajemen transportasi Jakarta. Pertama, Pembagian lokasi area untuk Pusat Pemerintahan, dan Bisnis hendaknya diatur secara komprehensif. Sehingga pada area tersebut menjadi representatif sebagai Ibu kota dan sebagai Pusat pemerintahan yang setiap saat harus menerima tamu negara dan kunjungan dari beberapa kepala negara dan pemerintahan, serta kawasan yang dialokasikan pebisinis dalam bisnis center dan pusat perbelanjaan yang mudah di datangi oleh para pebisnis dari lokal maupun manca negara menjadi tidak nyaman dan ikut merasakan kesemrawutan dalam aktivitas bisnisnya. (Area Ring 1). Seperti: wilayah Jalan Thamrin, Kuningan Jalan Gatot subroto dan Sudirman.

Kedua, pembangunan tata kota Jakarta. Dalam pembangunan pusat perbelanjaan, Mall, Sekolah, Komplek perumahan, Stadion Olahraga yang letaknya berada di tengah kota, jelas ini tidak mendukung ketertiban dan membuat lalu lintas serta tingkat kepadatan menjadi demikian tingginya baik pada hari kerja maupun pada hari libur sehingga menambah permasalahan lalu lintas di jalan maupun menambah banyak keruwetan di dalam kota (Area Ring 2). Belum lagi kalau terjadi tawuran antar pelajar dan apabila ada hujan besar/banjir. Seperti: Di wilayah/daerah Mal Casablanca, ITC Kuningan Pasar festival, Blok M Mal, dan sepanjang Jalan Sudirman/Plasa Semanggi, Plaza Senayan, Cempaka Mas. Tanah Abang dll. Dalam hal pengembangan kota dan pembangunan Gedung-gedung dan Bangunan tinggi, yang sering terjadi adalah: hak -hak masyarakat sebagai konsumen pemakai jalan raya yang banyak terkalahkan dan terabaikan. Mereka para Kontraktor Pengelola seolah tidak merasa bersalah mengambil hak pengguna jalan dengan menutup, memarkir, kadang mengalihkan lalu lintas didepan mereka ke jalur jalan lain yang lebih jauh dan memutar arah tanpa adanya kejelasan dan membuat macet diarea pembangunan yang tengah berlangsung tsb didaerah yang berada diluar Pusat pemerintahan dan Pusat bisnis tsb. (Area Ring 3). Seperti: sepanjang jalan raya dari Jalan S. 
Parman, MT. haryono,Cawang, Kelapa Gading. Jalan Suprapto, Mampang. Glodok, dan lain-lainnya.

Ketiga, penggolongan kendaraan yang berhak melintas. Pengguna dan pemakai jalan raya ternyata dari semua type dan jenis kendaraan, mulai: gerobak, bajaj, metromini, angkot, motor, bus, taxi, kendaraan umum lainnya selain kendaraan pribadi yang bebas lalu lalang tanpa ada pembatasan tahun dan jenis angkutan yang beroperasi, kecuali pada program 3 in 1 di jalan thamrin dan sekitarnya (itupun hanya membatasi jumlah penumpang saja dan bukan jenis dan tahun kendaraan).

Keempat, mengalihkan rute jalan tol dalam kota. Pembangunan Jalan Tol dalam kota ternyata juga tidak mampu mengurangi kepadatan berkendaraan di Jakarta, hal ini dikarenakan semua jenis kendaraan dari gol 1 s.d 3 masuk tumpah ruah di jalan Tol dalam kota yang sama. Padahal perlu dibuat pengaturan waktu lewat dan juga pemilahan kendaraan yang melintas serta jenis kendaraan yang mau melintas. Alternatif lain dibuat jalan Outer ring yang tidak harus melewati Tol Dalam kota. Tetapi dari arah Tangerang dibuat tol ke arah bekasi (langsung). Seperti: Truk Gol 3 dari Sumatera akan ke Semarang harus melalui Tol Kb. Jeruk dan Tol dalam kota, ada lagi Bus Antar kota yang langsung dari Merak - Bandung harus melalui jalan tsb. Sehingga dari pagi sampai malam di ruas tol tsb selalu PAMER (Padat Merayap). Begitu juga dari Bandara Cengkareng yang akan ke luar kota bisa keluar kota tidak harus masuk jalan tol dalam kota.

\section{Tahap Implementasi dari Pendekatan Segi Kepemimpinan, Strategi dan Pemikiran Kritis Sehubungan dengan Pengembangan Manajemen Transportasi Jakarta}

Melalui manajemen transportasi dengan segala inovasinya, Pemerintah Daerah DKI Jakarta diharapkan dapat membenahi wilayahnya untuk mengurangi buruknya kualitas udara Jakarta saat ini dan dimasa depan. Pelaksanaan Program Udara Bersih/PRODASIH yang sudah dan sedang berjalan perlu mendapat dukungan dari segenap warga Jakarta. Dimana peningkatan manajemen lalu lintas yang diarahkan untuk mengurangi kepadatan lalu lintas merupakan salah satu bagian dari program tersebut.

Jika ketiga faktor kekuatan yang ada di wilayah DKI Jakarta dijadikan faktor dominan dan dijadikan sumber kekuatan oleh Pemerintah daerah dalam mengembangkan manajemen transportasi Jakarta. Hal ini akan memberikan harapan yang berarti bagi pemerintah dan juga warga Jakarta. Keriasama yang baik antara pemerintah dan warga sangat diharapkan dalam hal ini. Pemberdayaan organisasi-organssasi kemasyarakatan serta forum-forum komunikasi yang ada di wilayah DKI, akan sangat membantu pada proses sosialisasi kebijakan pemda setempat di bidang pengembangan manajemen transportasi.

Serangkaian perubahan baik secara struktural maupun kultural akhirnya diperlukan demi pengembangan sektor transportasi massa yang lebih baik. Pentingnya perubahan struktural didasari dengan digulirkannya 
isu global yaitu Good Urban Governance oleh PBB melalui program pembangunannya untuk mengagendakan program dalam meningkatkan kualitas pelayanan publik. Peningkatan kualitas pelayanan publik pun menjadi salah satu tolok ukur pemerintahan kota yang ramah pada publik. Dalam hal ini perlu adanya intervensi pemerintah pusat dengan konsep Transportation Demand Management atau manajemen perkotaan berbasis sektor transportasi untuk mewujudkan good urban governance.

Perubahan kultural diperlukan, dengan mengubah paradigma mengenai transportasi massa menjadi lebih manusiawi. Dalam konteks ini, pandangan bahwa konsumen adalah raja juga harus diberlakukan di sektor transportasi massa. Kepuasan konsumen pun menjadi hal yang sangat prinsipil. Selain itu, budaya masyarakat transportasi, dari kalangan produsen hingga kalangan konsumen juga perlu diubah. Transformasi budaya agar angkutan umum menjadi pilihan utama masyarakat dalam bertaransportasi massa yang menawarkan kepuasan bagi penumpangnya mutlak diselenggarakan.

Dengan manajemen transportasi yang tepat, diharapkan akan meningkatkan penggunaan transportasi publik yang pada akhirnya dapat mengurangi jumlah kendaraan yang beroperasi di jalan-jalan Jakarta. Dalam membuat kebijakan manajemen transportasi, Pemerintah Daerah DKI Jakarta sedapat mungkin melibatkan banyak pihak yang berkepentingan dalam upaya pencapaian sebuah manajemen transportasi yang teruntegrasi di Jakarta tercinta ini, sehingga menjadikan udara Jakarta menjadi lebih bersih dan segar untuk dinikmati.

Ada beberapa sasaran yang bisa dilakukan oleh Pemerintah Daerah DKI Jakarta sehubungan dengan tahap implementasi pengembangan manajemen transportasi Jakarta, antara lain:

1) Pemda harus siap menjadi change agency, yaitu pihak yang merumuskan program-program angkutan kota dan lalu lintas jalan raya, yang dirumuskan melalui Perda atau SK Gubernur;

2) Dalam merealisasikan program-programnya, Pemda DKI perlu melakukan kontrol dan evaluasi per semester mengenai tepat atau berjalan/tidaknya program-program tersebut serta mengindentifikasikan kendala-kendalanya di lapangan;

3) Pemda perlu menetapkan suatu kebijakan dalam mengembangkan manajemen transportasi Jakarta dan mensosialisasikannya kepada segenap golongan/lapisan masyarakat melalui media cetak dan maupun media elektronik;

4) Pemda perlu meningkatkan sistem pelayanan transportasi publik yang berorientasi pada publik service, mudah dan murah serta memanusiawikan masyarakat;

5) Pemda perlu mengembangkan komunikasi dengan aparat dan instansi terkait dan juga melibatkan berbagai komponen dan forum-froum yang ada di wilayahnya, seperti: FORKABI, Forum Betawi Rembug; 
6) Pemda perlu mengoptimalkan peran dan fungsi lembaga yang bertugas untuk memonitor transportasi di wilayahnya, seperti TMC yang dikelola oleh POLDA METRO JAYA.

5. Peran dan Fungsi TMC (Transportation Management Center) oleh POLDA METRO JAYA Sebagai Lembaga Pengawas System Transportasi Jakarta

Sebagaimana Visi/Misi Polantas yang mampu menjadi pelindung, pengayom pelayan para pemakai jalan, sehingga masyarakat aman selama dalam perjalanan dan selamat sampai tujuan, selain itu juga memberikan bimbingan kepada masyarakat untuk meningkakan kesadaran dan ketaatan pada ketentuan peraturan lalu lintas. TMC di bangun dengan fasilitas dan sarana yang dibuat sejak tahun 2002 dengan menggunakan teknologi komputer yang terintegrasi yang diharapkan akan dapat membantu kecapatan informasi yang disampaikan kepada seluruh pihak yang berkepentingan, sehingga diharapkan mampu membantu pelaksanaan tugas polantas dalam menangani kemacetan, kecelakaan dan pelanggaran lalu lintas secara capat dan prodfesional.

Melihat latar belakang dan tujuan dibentuknya TMC ini sebenarnya sudah sangat tepat dan sesuai dengan kebutuhan sebagai bagian sistem Manajemen transportasi di ibukota. Namun kenyataan dilapangan Lembaga yang dibentuk POLDA METRO JAYA ini belum berfungsi optimal dan memiliki dampak berarti terhadap kecelaan dan kemacetan yang terjadi di Jakarta, seperti contoh: Pada tahun 2008 ini saja pada bulan Januari sebanyak 15 orang telah meninggal dunia dan 20 Orang pada bulan February, hal ini disebabkan karena kecelakaan lalu lintas bermotor/ kendaraan roda dua yang meninggal dunia karena jatuh dan luka-luka pada jalanan yang berlubang. Karena musim hujan yang terus menerus banyak jalan yang berlobang dan kondisi kendaraan terutama motor yang memang juga harus sudah tua dan Pengemudi harus mengganti perlengkapannya. Belum lagi kemacetan lalu lintas yang terjadi setiap pagi, siang dan malam hari baik di ruas jalan tol maupun non tol dengan diguyur hujan sepanjang hari dan lampu lalu lintas OFF/padam, belum lagi pada akhir tahun biasanya banyak pekerjaan saluran yang bergantian Instansi pelaksana/ pembangunannya, karena semua harus berjalan untuk anggaran yang harus habis dari Departemen terkait sehingga kemacetan tampaknya tidak pernah ada solusinya. Dan tidak ada yang pernah concern terhadap hak masyarakat pengguna jalan.

\section{Penutup}

Dalam hal pengembangan tata ruang kota dan hubungannya dengan manajemen transportasi di Jakarta, ada beberapa kendala yang dihadapi oleh pemerintah daerah setempat, antara lain: 
1. Sinkronisasi peraturan daerah (PERDA) dan UU tentang: Jakarta sebagai Ibukota Negara, pengembangan pembangunan di Jakarta, Pengaturan kendaraan umum dan pribadi, tentang ketentuan pengguna jalan dan masalah lalu lintas di jalan baik dalam kota dan lalu lintas jalan di daerah dan antar daerah.

2. Pengawasan, penegakkan dan pelaksanaan tertib peraturan lalu lintas oleh aparat dan petugas penegak hukum.

3. Taraf kepatuhan dan ikut serta peran warga masyarakat terhadap peraturan lalu lintas dan kontribusinya untuk mencegah kepadatan kendaraan di Jakarta

Ada dua paradigma dalam hal pengembangan manajemen transportasi, yaitu pertama prinsip car mobility dan kedua prinsip accesibility. Dengan prinsip car mobility, maka pemerintah banyak membangun sarana seperti jalan tol, jalan layang, jalan arteri. Jika ukuran transportasinya dengan prinsip accesibility, maka paradigma yang dibangun adalah bagaimana menciptakan infrastruktur transportasi yang yang mudah diakses publik. Seperti misalnya kereta, monorail, atau busway. Jika prinsip accesibility sudah mulai dibangun, maka akan ada pilihan bagi masyarakat. Orang akan sedikit demi sedikit meninggalkan mobil pribadinya dan memilih transportasi umum karena jauh lebih murah.

Ada beberapa pendekatan dari segi kepemimpinan, strategi dan pemikiran kritis dalam rangka mengembangkan manajemen transportasi Jakarta. Pertama, Pembagian lokasi area untuk Pusat Pemerintahan, dan bisnis hendaknya diatur secara komprehensif. Kedua, pembangunan tata kota Jakarta. Ketiga, penggolongan kendaraan yang berhak melintas. Keempat, mengalihkan rute jalan tol dalam kota. 


\section{Daftar Pustaka}

Adi, Rianto. Metodologi Penelitian Sosial dan Hukum, Jakarta: Granit, 2004.

Anderson, JND (editor). Changing Law in Developing Countries, London: George Allen and Unwin Ltd, 1993.

Badan Pusat Statistik. Statistik Indonesia: Statistical Yearbook of Indonesia 2005/2006, Jakarta: BPS, 2006.

Bintarto, R. Interaksi Desa-Kota dan Permasalahannya, (Jakarta: Ghalia Indonesia, 1983.

Dooley, David. Social Research Methods, third edition, New Jersey: Prentice Hall, 1995.

Everett M. Rogers. Diffusion of Innovations, New York: The Free Press, 1983

Izul, Muhammad. "Busway Culture: Budaya Baru Trasnportasi Jakarta", $<$ http://ezzelhague.multiply.com/journal/item/5>, diakses pada tanggal 18 Februari 2008.

Kristsadipun, "Kemacetan, Cermin Kelemahan Manajemen Transportasi", $<$ http://www.sinarharapan.co.id/berita/0211/02/eko11.html>, diakses pada tanggal 18 Februari 2008.

Koentjaraningrat. Metode-metode Penelitian Masyarakat, Cetakan ke VIII. Jakarta: PT. Gramedia, 1986.

Mamudji, Sri dan Hang Rahardjo. Tehnik Menyusun Karya Tulis Ilmiah, Bahan Kuliah Metodologi Penelitian Hukum. Edisi Keempat. Jakarta: 1999.

M.R. Bonavia. The Economics of Transport, Cambridge: Cambridge University Press, 1966.

Soekanto, Soerjono. Suatu Tinjauan Sosiologi Hukum Terhadap MasalahMasalah Sosial, cetakan kedua, Bandung: PT Citra Aditya Bakti, 1989).

Kurniawan, Teguh. "Manajemen Transportasi dan Kualitas Udara Jakarta", <http://www.sinarharapan.co.id/berita/0306/24/opi02.html>, diakses pada tanggal 18 Februari 2008.

Wigjnosoebroto, Soetandyo. HUKUM Paradigma, Metode dan Dinamika Masalahnya, Jakarta: ELSAM \& HUMA, 2002. 